\title{
Impact of silvering stage, age, body size and condition on reproductive potential of the European eel
}

\author{
Caroline M. F. Durif ${ }^{1,3, *}$, Sylvie Dufour ${ }^{2}$, Pierre Elie ${ }^{1}$ \\ ${ }^{1}$ Cemagref, Unité Ressources Aquatiques Continentales, Cemagref, 50 avenue de Verdun, 33612 Cestas, France \\ ${ }^{2}$ Biologie des Organismes Marins et Ecosystèmes, Muséum National d'Histoire Naturelle U.M.R. 5178 CNRS, 7 rue Cuvier, \\ 75231 Paris Cedex 05, France \\ ${ }^{3}$ Present address: Department of Biology, University of Oslo, PO Box 1066 Blindern, 0316 Oslo \\ and Institute of Marine Research-Austevoll, 5392 Storebø, Norway
}

\begin{abstract}
Deteriorating reproductive capacities are a possible cause for the decline in eel populations. However, since no sexually maturing adults have ever been found in the open ocean, there is no possible observation of this life-phase in the natural environment. To test whether eels display variations in their reproductive capacity, we investigated the response of the European eel Anguilla anguilla to artificially induced sexual maturation. The objective was to describe the variability in the maturation response of eels in terms of gonad weight and vitellogenin levels and to try and relate this variability to individual characteristics (length, condition, age and silvering stage). We carried out 3 sets of experiments in which sexual maturation was induced in female silver European eels from different locations using weekly carp pituitary extract (CPE) injections. External parameters of eels were measured every week, and several individuals were sacrificed at monthly intervals for blood and organ sampling. Although gonad weight in most treated eels increased by as much as $50 \%$ of total body weight, results showed that individual responses were highly variable. Part of this variability could be explained by individual characteristics of eels. Individuals which initially were the most advanced in the silvering process and had a high condition factor showed the best maturation response. Age of eels was correlated with energy stores, and it was shown that eels benefit from delaying their migration and reproduction. Furthermore, highest gonad development was obtained for eels measuring over $700 \mathrm{~mm}$ body length.
\end{abstract}

KEY WORDS: European eel · Anguilla anguilla $\cdot$ Females $\cdot$ Biometry $\cdot$ Sexual maturation $\cdot$ Life history Resale or republication not permitted without written consent of the publisher

\section{INTRODUCTION}

Since the 1980s, worldwide populations of eels have declined steeply (Moriarty 1986, ICES 2002, Dekker 2003). Causes mainly related to the freshwater life phase have been identified and studied, in particular overfishing and mortality caused by hydroelectric facilities. Marine causes for this decline have also been hypothesised: the global change in oceanic currents would affect larval migration making it impossible for them to reach the European coast; variations in the recruitment of eel larvae have also been correlated to changes in ocean productivity and hence a decrease in food for leptocephalus larvae (Castonguay et al. 1994 Desaunay \& Guerault 1997, McCleave et al. 1998, Feunteun 2002, Knights 2003). Deteriorating reproductive capacities of the adults have also been suggested as another cause in the decline of eel populations (Feuteun 2002, Dekker 2003).

The European eel spawns in the Sargasso Sea area, presumably in spring (Schmidt 1922, Tesch 1982, Kleckner \& McCleave 1988, Tesch \& Wegner 1990), approximately $6000 \mathrm{~km}$ from its continental habitat. It is only during its long-distance migration to the spawning grounds that the eel undergoes true sexual maturation (vitellogenesis and ovarian development), triggered by 
environmental factors encountered during this phase. However, the oceanic life phase of eels remains for the most part a mystery as no sexually maturing individuals have ever been caught or observed in the open sea.

At present, the only way to obtain sexually maturing eels is to artificially induce sexual maturation in migratory individuals (silver eels) caught in freshwater (for review see Dufour et al. 2003). The first successful ovarian development and ovulation in female silver eels Anguilla anguilla were obtained by Fontaine et al. (1964) using repeated injections of carp pituitary extract $(\mathrm{CPE})$ and a final injection of deoxycorticosterone. Since then, such experimental procedures have been used extensively, mainly with the purpose of obtaining viable larvae for aquaculture development of eels. Studies have focused solely on the establishment of successful protocols: dose and rhythm of hormone injections, timing and type of ovulation primers, optimal water temperature, salinity, and optimal body indices to predict ovulation (Sorensen \& Winn 1984, Prokhorchik 1986, Dufour et al. 1988, Ohta et al. 1997, Kagawa et al. 1998, Lokman \& Young 2000, Pedersen 2004, Palstra et al. 2005). Ovulated eggs and larvae were successfully obtained in a number of studies; however the proportion of ovulating females remained very low, as well as the fertility and hatchability of the eggs (Kagawa 2003). Accounts of eels (particularly true for Anguilla anguilla) not responding to gonadotropin injections are frequent and yet unexplained (Pedersen 2004, Palstra et al. 2005). Overall, there is evidence that although eels receive the same treatment, they display tremendous variability in their maturation response (Dufour unpubl. data, and this study). Here we hypothesised that this response reflects individual reproductive capacities. The present study aimed at investigating why eels display such variability, and if some part can be explained by the individual characteristics of eels.

During their growth phase, eels colonise a variety of different habitats (lakes, rivers, marshes, estuaries). Depending on the type of habitat, they will display great differences in body weight, body length and age at the time of their spawning migration. As gonad development relies on the fat stores of the fish, it is likely that these morphological differences will affect their reproductive potential. Individual differences at the start of the spawning migration are also found in their 'silvering stage'. Before eels are able to start sexual maturation, they undergo a true metamorphosis called silvering. This process marks the onset of puberty but also refers to the multiple modifications that will pre-adapt the eel to the oceanic long-distance migration. At the beginning of migration, 'silver eels' display variations in their degree of metamorphosis (Durif et al. 2005).
The objective of this study was to describe the variability in the response of eels in terms of gonad weight and vitellogenin production to standardised gonadotropic treatment (CPE injections), and to try and relate this variability to individual characteristics. To do this, sexual maturation was induced in groups of eels from different locations in France. Their capacity to mature was evaluated throughout the experimental periods using external indicators, and compared to their initial physiological and morphological characteristics.

\section{MATERIALS AND METHODS}

Sampling sites and eels. In order to obtain a wide range of sizes of silver eels, individuals were collected at 5 locations in France, which corresponded to very different types of aquatic systems (Fig. 1, Table 1). Eels from 2 large rivers, the Loire in Saint-Florent and the Rhine in Fessenheim (watersheds $=110000$ and $224000 \mathrm{~km}^{2}$, respectively), were obtained through commercial silver eel fisheries and using fyke nets. Eels from a coastal lake area, Sainte-Eulalie (watershed $=250 \mathrm{~km}^{2}$ ), were also obtained through a commercial fishery, but using a weir trap. Eels from the Nive river (watershed $=1000 \mathrm{~km}^{2}$ ) were caught using a trap installed at small hydroelectric power plant (see Durif et al. 2003 for a description of the trap). Finally, silver eels from a coastal brackish water marsh, Certes (watershed $=155 \mathrm{~km}^{2}$ ) were caught as they were leaving the reclaimed area through a weir trap. Eels were all caught during their downstream migration from

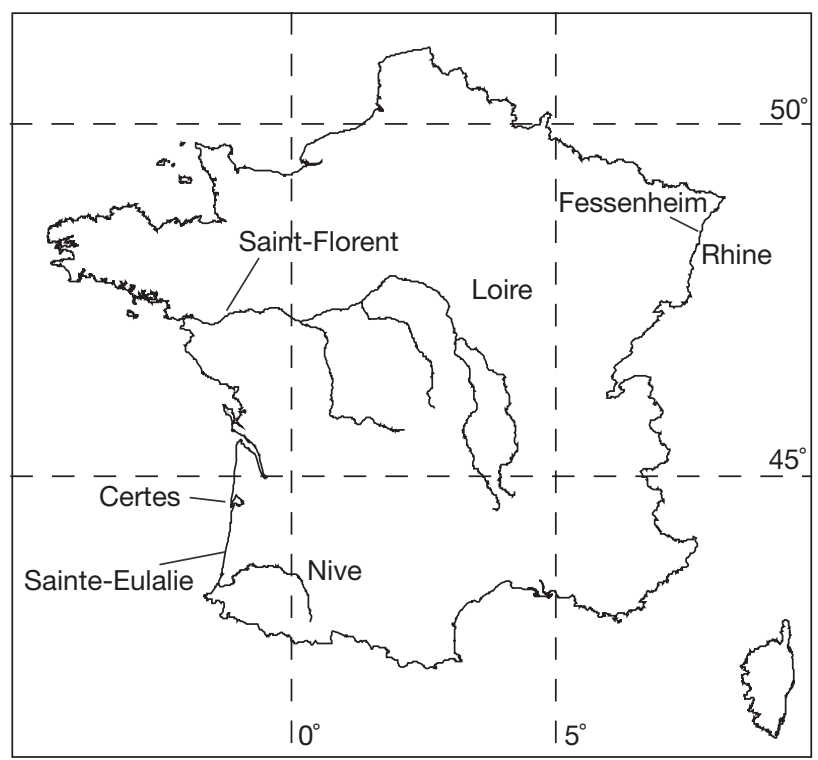

Fig. 1. Sampling sites for Anguilla anguilla. Only rivers pertaining to the study are shown 
Table 1. Anguilla anguilla. Number of treated and control individuals according to location. Individuals sacrificed initially, before any injections, are included in control column. Small number of eels from Certes in Year 3 was due to high mortality for that group of individuals

\begin{tabular}{|lcccccc|}
\hline \multirow{2}{*}{ Location } & \multicolumn{2}{c}{ Year 1 } & \multicolumn{2}{c}{ Year 2 } & \multicolumn{2}{c|}{ Year 3 } \\
& Control & Treated & Control & Treated & Control & Treated \\
\hline Loire & 83 & 52 & 28 & 55 & 39 & 32 \\
Nive & 14 & 9 & 34 & 27 & - & - \\
Certes & - & - & 10 & 12 & 4 & 1 \\
Rhine & - & - & - & - & 24 & 20 \\
Sainte-Eulalie & - & - & - & - & 17 & 32 \\
Total & 97 & 61 & 112 & 94 & 84 & 85 \\
\hline
\end{tabular}

November to December. Only females were chosen for the experiments, and they measured between 450 and $1000 \mathrm{~mm}$

Tanks and housing. Eels were transported in oxygenated tanks to the holding facilities at the Cemagref Aquaculture station of Saint-Seurin after their capture. At their arrival on site, the fish were measured (see later subsection on external biometric measurements) and PIT (passive integrated transponder) tags were inserted into the dorsal muscle. Eels were housed in different tanks (with isolated water flow) according to their sampling site. Acclimation to a salinity of 34 was done over a $3 \mathrm{wk}$ period. One reservoir tank supplied artificial seawater (Instant Ocean salts), and therefore water conditions (temperature and salinity) were identical in all tanks. Eels were submitted to natural photoperiod and outdoor temperature, as tanks were located under a clear plastic shelter. Mean water temperature varied between an average minimum of $8^{\circ} \mathrm{C}$ in January (at the start of the experiments) to an average maximum of $26^{\circ} \mathrm{C}$ in June. Migratory eels fast naturally, so they were not fed throughout the experiment.

Gonadotropic treatment and preparation of carp pituitary extract (CPE). We homogenised $1 \mathrm{~g}$ of lyophilised carp pituitary powder ('Catfish' company, Den Bosch) in $15 \mathrm{ml}$ of extraction buffer: $0.15 \mathrm{M} \mathrm{NaCl}$, $0.01 \mathrm{M}$ phosphate buffer $\mathrm{pH} 7.4$, containing $0.04 \mathrm{mg}$ $\mathrm{ml}^{-1}$ protease inhibitor Aprotinin (Sigma). The homogenate was left overnight at $4^{\circ} \mathrm{C}$. After centrifugation $(4000 \times g)$ for $10 \mathrm{~min}$, the supernatant was removed and stored at $4{ }^{\circ} \mathrm{C} ; 5 \mathrm{ml}$ of extraction buffer was added to the pellet. The solution was frozen, defrosted, centrifuged and the supernatant was removed and stored at $4^{\circ} \mathrm{C}$. This manipulation was repeated twice.

Before any manipulation (tagging, measurements, hormone injections), eels were anaesthetised with a 1:10 solution of clove oil dissolved in ethanol $70 \%$. Eels received 1 perivisceral injection a week of carp pituitary extract at a dose equivalent to $20 \mathrm{mg}$ pituitary powder $\mathrm{kg}^{-1}$ body weight, according to a method pre- viously developed (Fontaine et al. 1964, Dufour et al. 1993).

External biometric measurement and hormone injection protocol. The following external measurements were taken prior to any hormone injection and every 2 wk throughout the experimental period: body length, pectoral fin length and vertical and horizontal eye diameters. Mean eye diameter, Dm, was calculated as the mean of both eye diameters. Body diameter was measured with the calliper placed around the anterior part of the body at the dorsal fin level. Body weight was recorded every week to calculate the condition factor. Since Fulton's condition factor was significantly correlated with body length, relative condition (LeCren 1951) was used to compare body weights:

$$
\mathrm{Kn}=\frac{\mathrm{Wb}}{\mathrm{W}^{\prime}} \times 10^{5}
$$

where $\mathrm{Wb}$ is the body weight and $\mathrm{W}^{\prime}$ is the predicted length-specific mean weight for the sample. $W^{\prime}$ was here equal to (body length) ${ }^{3.21}$. The initial stage of eels relative to the silvering process was determined using body length, $\mathrm{Wb}$, fin length and $\mathrm{Dm}$ measured at their arrival on site according to the classification system described by Durif et al. (2005) and Durif \& Elie (in press).

Organ sampling. Control and treated eels were sacrificed at regular intervals for up to $24 \mathrm{wk}$ of treatment. Eels were decapitated after anaesthesia. Ovaries, liver and digestive tract were removed and weighed. Blood samples were taken and centrifuged, and plasma was stored for vitellogenin assay measurements. Vitellogenin plasma levels were assayed by immuno-enzymatic assays specifically developed for Anguilla anguilla according to Burzawa-Gerard \& Dumas-Vidal (1991).

Age determination. Otoliths were collected during each monthly sacrifice, cleaned in distilled water, and stored in dry Eppendorf tubes. They were embedded in synthetic resin (Synolithe) and ground with a polishing machine (Streuers Rotopol-35) until the nucleus was reached. Etching was done using EDTA at a concentration of $10 \%$ for $15 \mathrm{~min}$. Otoliths were then stained with Toluidine blue (concentration 5\%). The first ring was considered as Year 1 of the eel's life. Age was determined on 142 eels (from all the locations except Certes) out of 240 treated individuals.

Experimental design. Eels were treated between December 2000 and May 2001 (Year 1), January 2001 to June 2002 (Year 2), and January 2002 to May 2003 (Year 3). Eels from the Loire were tested during all 3 experiments. Individuals from the other locations were 
tested according to Table 1 . The 3 experiments involved a total of 533 eels, among which 240 received a gonadotropic treatment (CPE) and 293 were controls.

Evaluation of maturation response. The level of response of eels to the gonadotropin treatment was first evaluated through the weight of ovaries and vitellogenin levels. However, this limited the number of comparisons since eels had to be sacrificed to obtain these parameters. Therefore, correlations between external parameters and gonad development as well as vitellogenin levels were first calculated to obtain an external indicator of maturation state. These external parameters, which were measured at regular intervals on every eel, were thus used to assess the maturation response of eels as well as the changes occurring during sexual maturation. Eels were asynchronous in reaching sexual maturation; therefore each individual

Table 2. Abbreviations used in text

\begin{tabular}{|lcc|}
\hline Full name & Measurement & $\begin{array}{c}\text { Standardised } \\
\text { variable }\end{array}$ \\
\hline $\begin{array}{l}\text { Internal } \\
\text { Gonad weight }\end{array}$ & $\mathrm{Wg}$ & $\mathrm{GW}$ \\
Liver weight & $\mathrm{Wl}$ & $\mathrm{LW}$ \\
$\begin{array}{l}\text { Digestive tract weight } \\
\text { Vitellogenin level }\end{array}$ & $\mathrm{Wdt}$ & $\mathrm{DTW}$ \\
External & $\mathrm{Vg}$ & $\mathrm{VTG}$ \\
Body length & $\mathrm{Lt}$ & \\
Body weight & $\mathrm{Wb}$ & $\mathrm{Kn}_{\text {(relative condition) }}$ \\
Body diameter & $\mathrm{Db}$ & $\mathrm{BD}_{\mathrm{i}}$ : initial \\
& & $\mathrm{BD}_{\mathrm{m}}$ : maximum \\
Mean eye diameter & $\mathrm{Dm}$ & $\mathrm{ED}_{\mathrm{i}}$ : initial \\
& & $\mathrm{ED}_{\mathrm{m}}$ : maximum \\
Pectoral fin length & & $\mathrm{PF}_{\mathrm{i}}$ : initial \\
& & $\mathrm{PF}_{\mathrm{m}}$ : maximum \\
\hline
\end{tabular}

was characterised by a set of values corresponding to: the highest pectoral fin length, body diameter, eye diameters and body weight measurements it ever reached during its trial and before it spontaneously released its oocytes.

In order to compare maturation response regardless of any size effect, all measurements were standardised to body length. Influence of body size on reproductive capacities was analyzed separately. Measurements (except for body weight) were first log-transformed then standardised following Claytor \& MacCrimmon (1987), using the formula:

$$
\text { Var_std = Var }-\left(\mathrm{M}\left(\mathrm{Lt}-\mathrm{Lt} \_ \text {mean }\right)\right)
$$

where Var_std is the corrected variable, Var is the original variable, $\mathrm{M}$ is the slope of the regression of the variable on total body length (Lt), and Lt_mean is the mean length of the eels in the sample. Henceforth, standardised variables are referred to as $\mathrm{BD}_{\mathrm{m}}$ for maximum body diameter, $\mathrm{ED}_{\mathrm{m}}$ for maximum eye diameter and $\mathrm{PF}_{\mathrm{m}}$ for maximum pectoral fin length. Standardised initial measurements (measured before any hormone injection) are referred to as $\mathrm{BD}_{\mathrm{i}}, \mathrm{ED}_{\mathrm{i}}$ and $\mathrm{PF}_{\mathrm{i}}$. Internal parameters were also standardised according to body length: GW for gonad weight, LW for liver weight and DTW for digestive tract weight. Vitellogenin was only log-transformed as it was not correlated to body length, and this variable is referred to as VTG. Abbreviations are listed in Table 2. To obtain an index to characterise the overall response of eels to hormonal injections regardless of the time they were sacrificed, we chose an external parameter that had been measured regularly during the experiments. $\mathrm{BD}_{\mathrm{m}}$ was chosen since it was highly correlated with GW ( $\mathrm{r}=0.80$, Table 3$)$. Values of $\mathrm{BD}_{\mathrm{m}}$ were plotted against the corresponding number of

Table 3. Anguilla anguilla. Pearson correlation matrix calculated on morphological and physiological descriptors of treated eels. Significant correlation coefficients in boldface (Bonferroni, p < 0.05). GW: standardised gonad weight, VTG: log (vitellogenin), LW: standardised liver weight, DTW: standardised digestive tract weight, Kn: relative condition factor, ED: standardised eye diameter, PF: standardised pectoral fin length, BD: standardised body diameter; m: max; i: initial

\begin{tabular}{|c|c|c|c|c|c|c|c|c|c|c|c|c|c|}
\hline & GW & VTG & LW & DTW & $\mathrm{Kn}_{\mathrm{m}}$ & $\mathrm{ED}_{\mathrm{m}}$ & $\mathrm{PF}_{\mathrm{m}}$ & $\mathrm{BD}_{\mathrm{m}}$ & $\mathrm{Kn}_{\mathrm{i}}$ & $\mathrm{ED}_{\mathrm{i}}$ & $\mathrm{PF}_{\mathrm{i}}$ & $\mathrm{BD}_{\mathrm{i}}$ & Age \\
\hline GW & 1.00 & & & & & & & & & & & & \\
\hline VTG & 0.58 & 1.00 & & & & & & & & & & & \\
\hline LW & 0.65 & 0.43 & 1.00 & & & & & & & & & & \\
\hline DTW & -0.60 & -0.34 & -0.23 & 1.00 & & & & & & & & & \\
\hline $\mathrm{Kn}_{\mathrm{m}}$ & 0.59 & 0.38 & 0.61 & -0.23 & 1.00 & & & & & & & & \\
\hline $\mathrm{ED}_{\mathrm{m}}$ & 0.66 & 0.50 & 0.46 & -0.49 & 0.57 & 1.00 & & & & & & & \\
\hline $\mathrm{PF}_{\mathrm{m}}$ & 0.10 & 0.11 & 0.03 & 0.02 & 0.28 & 0.23 & 1.00 & & & & & & \\
\hline $\mathrm{BD}_{\mathrm{m}}$ & 0.80 & 0.41 & 0.71 & -0.41 & 0.87 & 0.63 & 0.19 & 1.00 & & & & & \\
\hline $\mathrm{Kn}_{\mathrm{i}}$ & 0.43 & 0.39 & 0.55 & -0.02 & 0.81 & 0.45 & 0.29 & 0.58 & 1.00 & & & & \\
\hline $\mathrm{ED}_{\mathrm{i}}$ & 0.08 & 0.10 & 0.14 & 0.1 & 0.12 & 0.46 & 0.21 & 0.17 & 0.13 & 1.00 & & & \\
\hline $\mathrm{PF}_{\mathrm{i}}$ & 0.10 & 0.13 & 0.08 & 0.11 & 0.35 & 0.19 & 0.77 & 0.23 & 0.40 & 0.23 & 1.00 & & \\
\hline $\mathrm{BD}_{\mathrm{i}}$ & 0.43 & 0.32 & 0.50 & -0.11 & 0.69 & 0.55 & 0.05 & 0.60 & 0.68 & 0.14 & 0.18 & 1.00 & \\
\hline Age & 0.36 & 0.37 & 0.42 & 0.09 & 0.43 & 0.24 & -0.08 & 0.43 & 0.39 & -0.03 & 0.11 & 0.30 & 1.00 \\
\hline
\end{tabular}


injections (i.e. number of injections an eel had received to reach its $\mathrm{BD}_{\mathrm{m}}$ value). Exponential curves were fitted to each yearly set of data by the least square method (Fig. 2). Eels that displayed a $\mathrm{BD}_{\mathrm{m}}$ value lower than the predicted value (negative residual) were classified into the LMR group (low maturation response), and eels with a higher than predicted $\mathrm{BD}_{\mathrm{m}}$ were assigned to the HMR group (high maturation response). This was done separately for each yearly experiment.

Statistics. Mean GW, VTG, LW and DTW between control and treated individuals were compared using Student's $t$-tests. Pearson correlations between standardised variables were calculated, and their significance determined using a Bonferroni test. Differences in central tendency were evaluated using 1-way ANOVA, after checking for homogeneity of variance
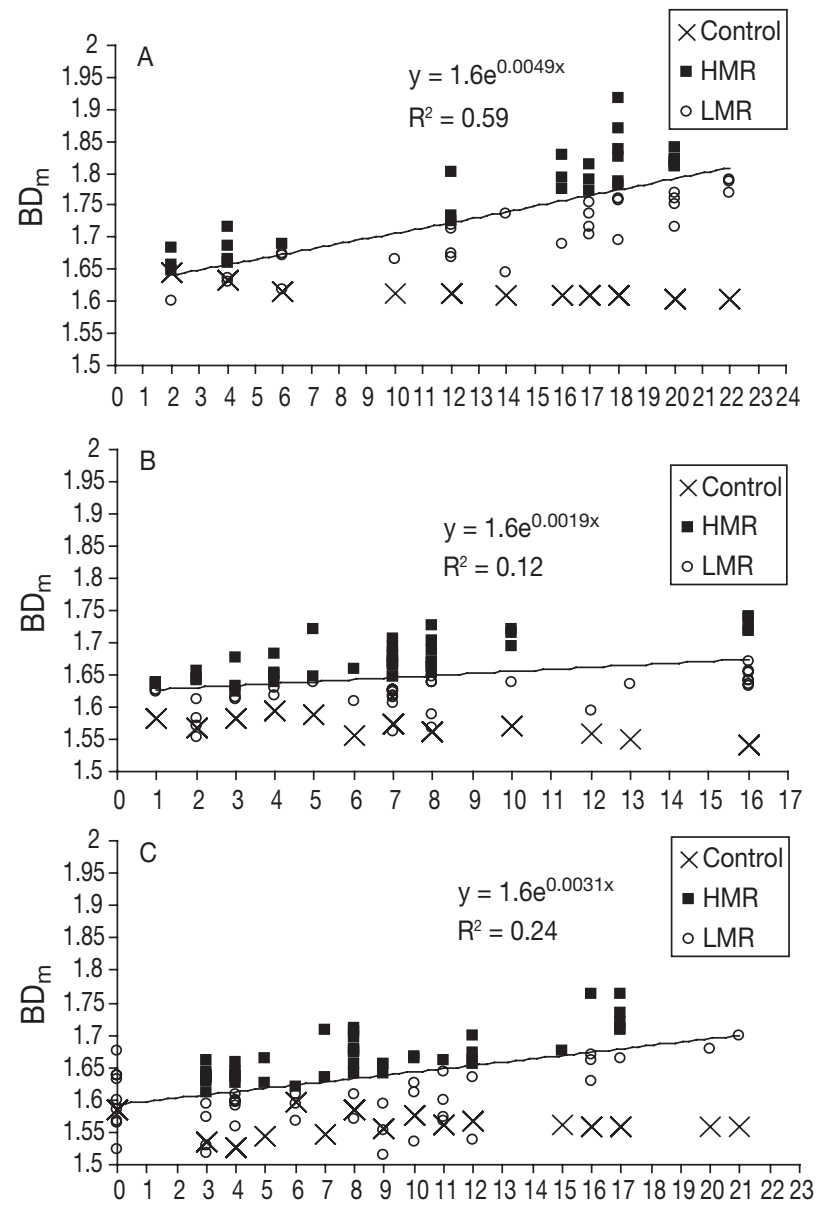

No. of CPE injections

Fig. 2. Anguilla anguilla. Relationship between maximum body diameter $\left(\mathrm{BD}_{\mathrm{m}}\right)$ of treated and control eels and number of weekly CPE (carp pituitary extract) injections. Exponential curves were fitted to the data separating treated eels with low maturation response (LMR) from those with high maturation response (HMR). (A) Year 1; (B) Year 2; (C) Year 3
(Bartlett's test). To assess the effect of body length on the eel's gonad development, individuals were first grouped into $100 \mathrm{~mm}$ size classes. The slopes of the linear relationships between log-transformed raw gonad weight, $\log (\mathrm{Wg})$, and the number of injections for each size class were compared using ANCOVA. Pairwise comparisons were done with a Bonferroni test. A significance level of $5 \%$ was used in all tests. Statistics were performed using SPSS Version 10.

\section{RESULTS}

\section{Changes in internal parameters during induced sexual maturation}

Gonads of most treated eels underwent a significant increase, as much as $50.3 \%$ of total body weight (mean value in initial controls was $1 \%$ ). However, variability in individual responses to the treatment was very high. The coefficient of variation $(\mathrm{CV}=$ mean/standard deviation) calculated on GW of treated eels at each organ sampling date ranged between 4 and 59\%. Differences in GW between treated and control eels from the Loire (which were tested in all $3 \mathrm{yr}$ ) became significant after the 4th injection (Fig. 3). The GW of treated eels then increased gradually until oocytes were spontaneously released starting at the 18th injection. The GW value of control eels decreased regularly throughout all 3 experiments. After 21 to $24 \mathrm{wk}$, mean GW of control eels was reduced by 33 to $42 \%$ depending upon the year.

Vitellogenin levels were always significantly higher in treated eels. At the beginning of sexual maturation, vitellogenin increased rapidly: from $5 \mu \mathrm{g} \mathrm{ml}^{-1}$ in initial control eels to around $15646 \mu \mathrm{g} \mathrm{ml}^{-1}$ after the 4 th injection, and peaked at $104821 \mu \mathrm{g} \mathrm{ml}^{-1}$ after the 18th injection (Fig. 3, Year 3). Vitellogenin levels during Year 2 were only determined in the initial samples. Values were slightly lower than they were in the Year 1 experiment, although they were still significantly higher in treated eels than in controls after the 2nd injection.

The digestive tract of treated eels regressed (Fig. 4), but differences from control eels were not always significant (no differences in Year 2). At the time of completed maturation (around $18 \mathrm{wk}$ ), it consisted only of a very thin layer of tissue embedded in the gonads.

In almost all cases, LW of sexually maturing eels was significantly higher than in control eels, starting at the 2nd injection (Fig. 4), indicating that the weight of the liver increased as eels became sexually mature. However, trends in liver weights differed between years, with a slight increase during Years 1 and 3, and a decrease during Year 2. 

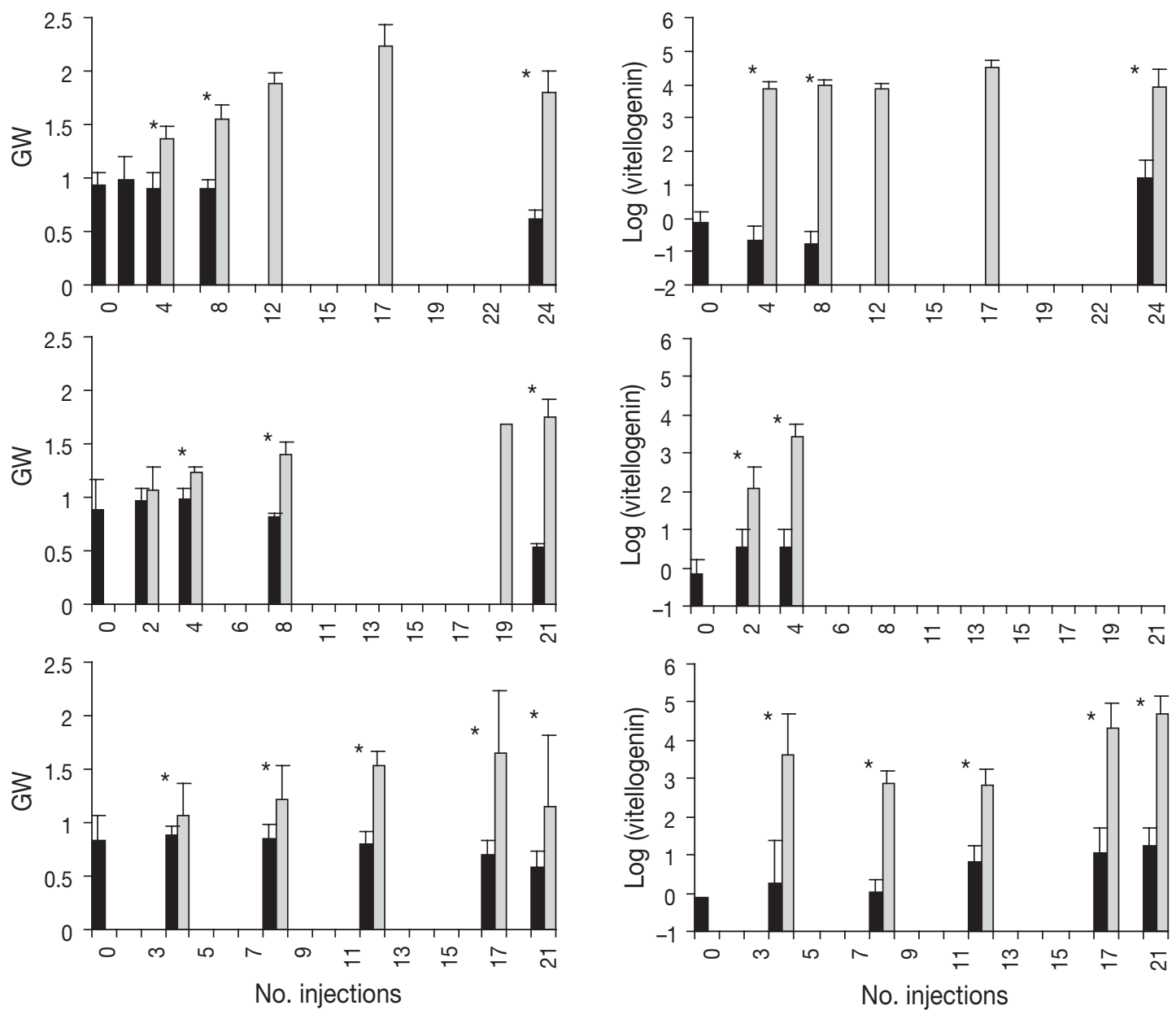

Fig. 3. Anguilla anguilla. Changes in standardised weights of gonads (GW) and vitellogenin level of individuals from the Loire during artificially induced sexual maturation (weekly gonadotropin injections). The 3 trials were carried out over 3 yr. Black and grey bars represent control and experimental fish, respectively. ${ }^{*}$ Significant differences (Student's $t$-tests, $p<0.05$ )

\section{Relationships between variations in internal and external parameters during induced sexual maturation}

Some of the internal and external parameters were correlated. GW increased with increasing VTG and LW, while DTW decreased (Table 3). The GW was also significantly correlated with external descriptors that reflect energy stores: initial and maximum relative condition $\left(\mathrm{Kn}_{\mathrm{i}}, \mathrm{Kn}_{\mathrm{m}}\right)$, as well as initial and maximum body diameter $\left(\mathrm{BD}_{\mathrm{i}}, \mathrm{BD}_{\mathrm{m}}\right)$. The length of the pectoral fin did not increase during sexual maturation; therefore $\mathrm{PF}_{\mathrm{m}}$ was not correlated with any parameter. However eye diameter (ED) increased with increasing number of hormone injections, and $\mathrm{ED}_{\mathrm{m}}$ was significantly correlated with GW, VTG and all associated parameters ( $\mathrm{LW}, \mathrm{DTW}, \mathrm{Kn}_{\mathrm{m}}, \mathrm{BD}_{\mathrm{m}}, \mathrm{Kn}_{\mathrm{i}}$, and $\mathrm{BD}_{\mathrm{i}}$ ). Initial length of the pectoral fin $\left(\mathrm{PF}_{\mathrm{i}}\right)$ was linked to relative condition, both initial and maximum.
The age of 327 eels was determined (Loire 217, Rhine 24, Sainte-Eulalie 53, Nive 26, Certes 7). Age was extremely variable within and between sites, ranging from 5 to $27 \mathrm{yr}$ (Fig. 5). It was positively correlated with several descriptors linked to the energy stores of eels: $L W, \mathrm{BD}_{\mathrm{m}}, \mathrm{Kn}_{\mathrm{m}}$, and $\mathrm{Kn}_{\mathrm{i}}$. The oldest eels also displayed the highest levels of vitellogenin.

\section{Variability in individual maturation response}

Initial silvering stage and maturation response. At the beginning of the experiment, eels were at various silvering stages (from Stage FII to Stage FV, according to the classification established by Durif et al. 2005). None of the eels that were at the yellow stage (11 individuals, Stage FII: sexually differentiated eels but with very limited gonad development) matured, and their 

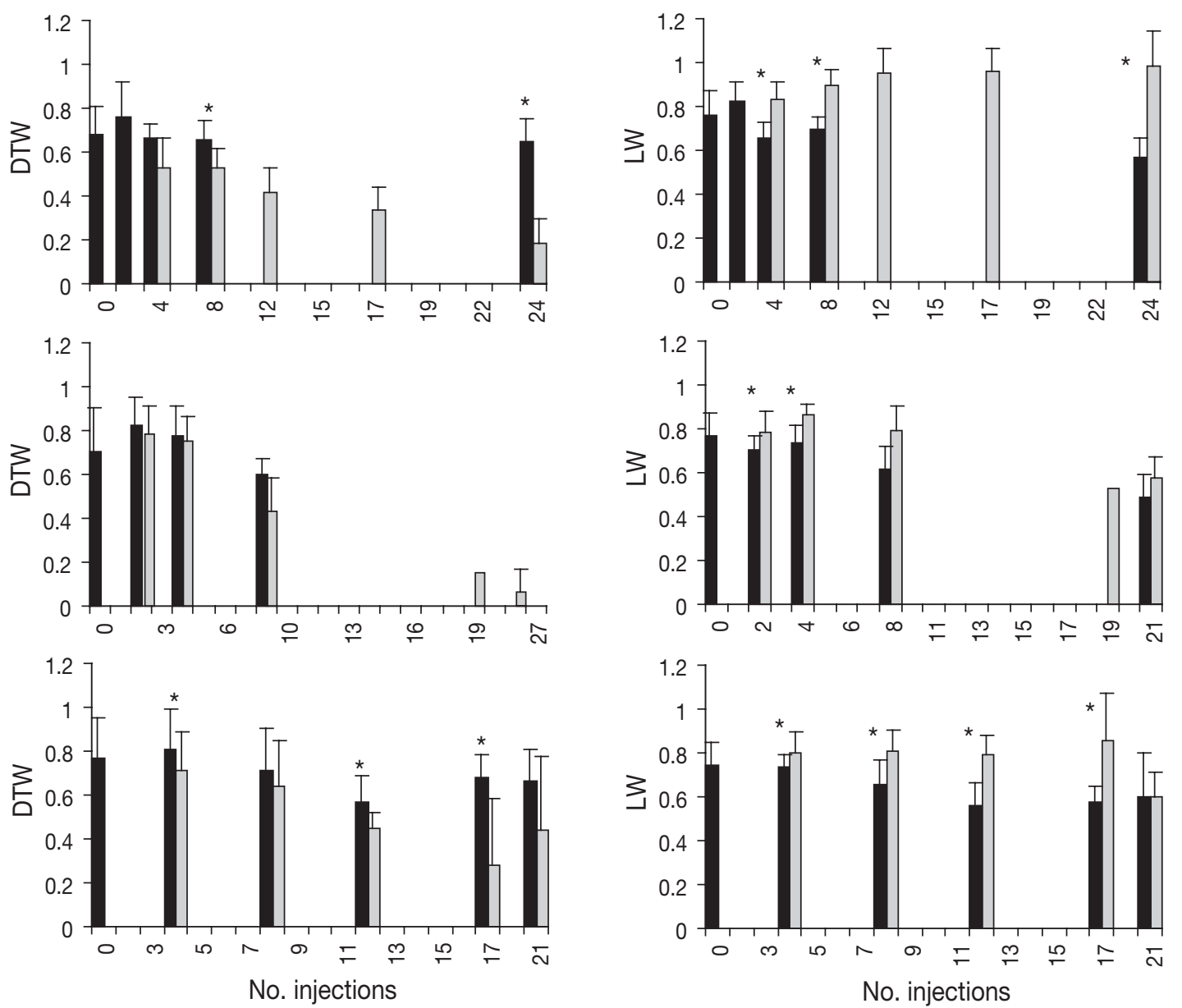

Fig. 4. Anguilla anguilla. Changes in standardised weights of digestive tract (DTW) and liver (LW) of eels from the Loire during artificially induced sexual maturation (weekly gonadotropin injections). The 3 trials were carried out over 3 yr. Black and grey bars represent control and experimental fish respectively. *Significant differences (Student's $t$-tests, $\mathrm{p}<0.05$ )

body diameter (BD) decreased from the start. The majority $(60 \%)$ of pre-silver eels (Stage FIII: slightly developed gonads but no regression of digestive tract), displayed low maturation response. In the same way, $65 \%$ of Stage FIV eels (silver eels at the beginning of migration) were in the LMR group. Finally, the majority $(56 \%)$ of $\mathrm{FV}$ eels (last silvering stage) displayed high maturation response, but $44 \%$ still showed low maturation response.

Initial condition and maturation response. To remove the stage effect, only FV eels were used in further comparisons. Eels belonging to the HMR group had a higher $\mathrm{Kn}_{\mathrm{i}}$ and $\mathrm{BD}_{\mathrm{i}}$ than eels in the LMR group. Although this was true for all $3 \mathrm{yr}$, differences were statistically significant in Years 2 and 3 only (Fig. 6).

Age and maturation response. Eels from the different locations showed differences in age distributions. Eels from the 2 larger rivers, the Loire and the Rhine, showed the widest variability in age, ranging from 6 to $23 \mathrm{yr}$ in the Loire and between 6 and $19 \mathrm{yr}$ in the Rhine. Eels from Sainte-Eulalie were between 5 and $13 \mathrm{yr}$, while on the Nive they showed greater ages (between 13 and $24 \mathrm{yr}$ ). Within each location and according to each stage, differences between the LMR and HMR group were either not significant (Student's $t$-test, $\mathrm{p}<$ 0.05) or there were too few individuals for testing (Fig. 5).

Body length and gonad development. Overall, results showed that raw gonad weight $(\mathrm{Wg})$ followed an exponential increase with increasing number of injections. Moreover, larger eels produced more gonads, and this relationship was also exponential. The 4 eels that were in the $400 \mathrm{~mm}$ class $(400<\mathrm{Lt}<$ $500 \mathrm{~mm}$ ) hardly matured, as Wg only reached $10 \mathrm{~g}$ after 12 injections $(\mathrm{Wg}=2.5 \mathrm{~g}$ for control eels of the same size class). For larger eels, linear regressions were calculated as $\log (\mathrm{Wg})$ against the number of 


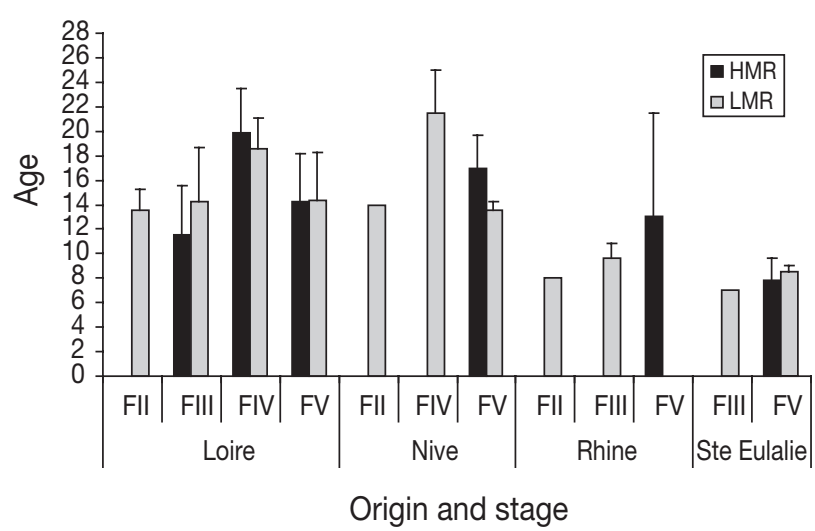

Fig. 5. Anguilla anguilla. Mean $( \pm \mathrm{SE})$ age (yr) of eels from different locations and at different silvering stage (FII, FIII,

FIV, FV). HMR: high maturation response eels; LMR: low maturation response eels
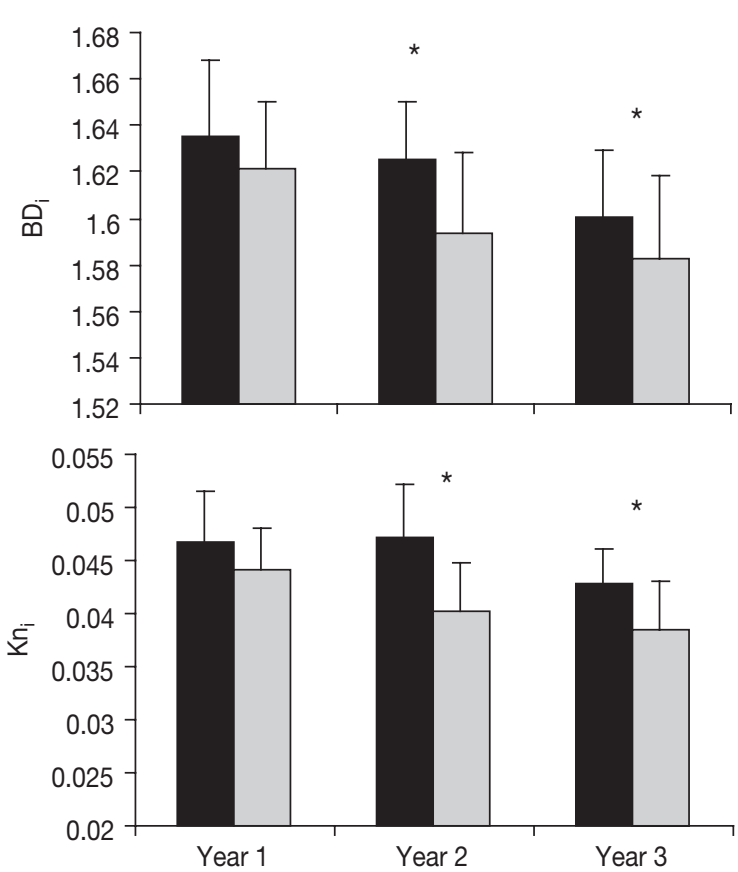

Fig. 6. Anguilla anguilla. Mean of initial parameters according to their maturation response. Grey bars: low maturation response; black bars: high maturation response; $\mathrm{BD}_{\mathrm{i}}$ : initial standardised body diameter; $\mathrm{Kn}_{\mathrm{i}}$ : initial relative condition; *significant differences (1-way ANOVA, $\mathrm{p}<0.05$ )

injections. Pearson correlation coefficients were respectively equal to $r=0.79(p<0.05), r=0.84(p<$ $0.05), r=0.93(p<0.05), r=0.89(p<0.05)$ for the 500, 600,700 and $800 \mathrm{~mm}$ classes. The slopes all differed significantly (ANCOVA, p < 0.05), but the steepest belonged to the $700 \mathrm{~mm}$ class indicating that these eels were the most efficient in producing gonads relative to their body size (Fig. 7).

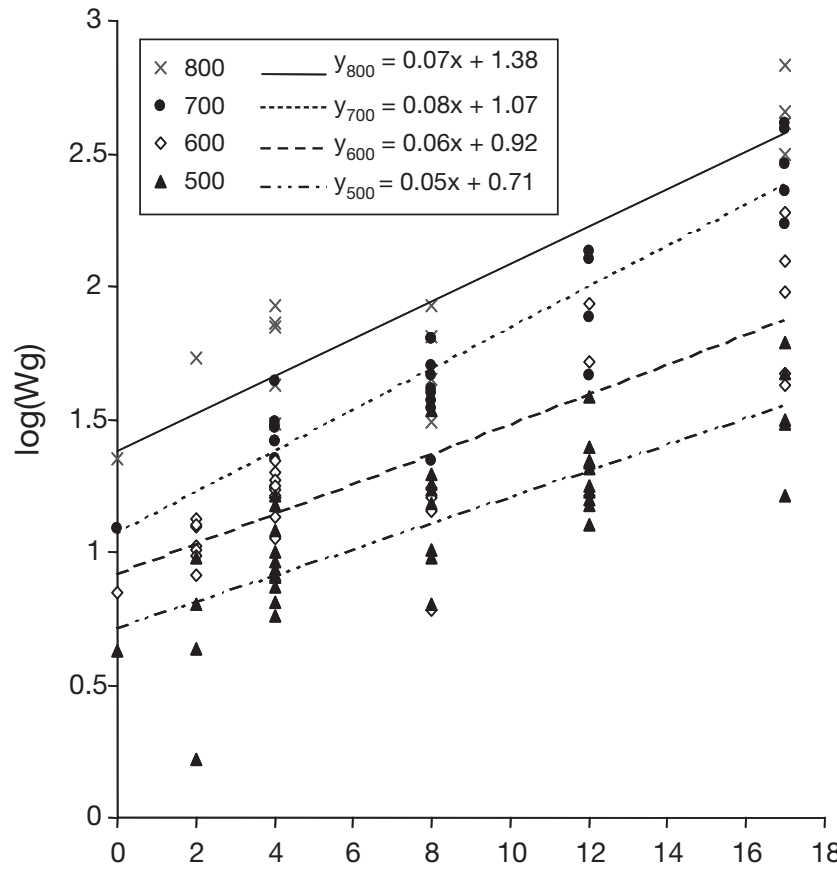

No. injections

Fig. 7. Anguilla anguilla. Log-transformed weight of gonads according to number of $\mathrm{CPE}$ injections. Linear regression lines were fitted for 500,600, 700, and $800 \mathrm{~mm}$ size classes

\section{DISCUSSION}

\section{Artificially induced maturation and reproductive capacity}

ICES (1999) stated that the European eel stock is outside safe biological limits and recommended setting escapement targets. This study is the first to try and 'quantify the quality' of future spawners. As it is not possible to observe naturally maturing eels, evaluating reproductive capacities of eels remains a difficult task. Here the response of eels to standardised gonadotropin injections was used as a proxy to evaluate reproductive capacity. This maturation response was characterised by gonad weight, which reflects fecundity, and vitellogenin level, which is the precursor protein for yolk. High variability in the maturation response was observed, as the coefficient of variation relative to gonad weight of eels having received the same number of hormone injections ranged between 4 and $59 \%$.

Eels within the same year and location were handled identically. This variability was therefore not linked to differences in capture and handling procedures but to differences in individual morphological and physiological characteristics. Although sexual maturation was necessarily artificially induced, eels in their nat- 
ural spawning grounds probably exhibit similar variability in their reproductive capacities.

Some of the eels that were classified into the LMR group may have represented late spawners that simply took more time to reach full sexual maturation. However, for more than half of the LMR eels (58\%), maximal body diameter was reached before the last measurement (at the time of sacrifice). These individuals did not show any further gonad (body diameter) development regardless of the additional injections, indicating inability to complete sexual maturation. This strongly suggests that these individuals would not have become efficient spawners.

\section{Influence of silvering}

The eels in the experiments were all caught during the season of their downstream migration using specific fishing gear that targets downstream migrants; however, several of them were not at the 'silver stage', such as the FII individuals (or yellow eels). Although they had been actively swimming downstream, these eels were not ready to undergo sexual maturation since they did not respond at all to the hormonal treatment. This was also reported by Burzawa-Gerard et al. (1994) who showed that as opposed to silver eels, yellow eels lack specific E2 receptors for vitellogenin synthesis. Eels at Stages FIII (pre-migrant) and FIV (early migration) showed some response but most individuals did not respond well to the treatment. Stage FIV corresponds to eels at the beginning of fasting and downstream swimming. Although these eels had undergone most of the modifications of silvering, they showed lower response than Stage FV eels which had presumably been migrating for a longer time. Active swimming may have triggered the last steps of the silvering process, as suggested by Durif et al. (2005). This is further supported by the recent findings of van Ginneken et al. (unpubl.), who demonstrated that active swimming significantly increases pituitary levels of LH-like gonadotropin, plasma levels of estradiol, as well as oocyte diameters of eels.

The downstream migration of eels generally occurs from October to December. Migration runs are not continuous, and only occur during specific environmental windows (Durif et al. 2003). It has been hypothesised that in the case of a very large river (e.g. the Loire, approximately $1000 \mathrm{~km}$ long), eels may need more than 1 migratory season to reach the sea and may reverse to an earlier stage outside the migration period (Durif et al. 2003). The present study also supports this through 2 results: (1) control eels showed regression of gonads throughout the experiment (between 33 and $42 \%$ ), and therefore were reversing to a 'resident stage'; (2) intermediate stages of silvering (i.e. FIII and FIV) did not respond well to hormonal treatment. Thus it appears that completion of silvering is an essential step for the outcome of sexual maturation. This would be of particular importance for future aquaculture purposes.

\section{Influence of energy stores}

Among the 'most advanced silver' individuals (Stage FV eels), the best response came from eels with the highest initial condition factor and largest initial body diameter. In other words, the initial state of the eel in terms of energy stores partly explained the variability in subsequent sexual maturation. For eels in the $700 \mathrm{~mm}$ size class, Fulton's condition factor, using $\mathrm{W}^{\prime}=$ $(\mathrm{Lb})^{3}$, for high reproductive potential spawners was higher than 0.2. High energy stores at the beginning of their migration have a direct effect on the capacity of eels to produce gonads. In the eel's natural environment, high fat content is also crucial for them to swim across the Atlantic Ocean (van den Thillart et al. 2004). Therefore, growth conditions (linked to habitat quality) of eels are particularly important for sustaining eel populations, as they will affect not only their capacity to reach their spawning grounds, but also their capacity to undergo sexual maturation.

Liver weight was highly correlated with gonad development and vitellogenin levels. The liver stores energy as glycogen and is directly implicated in vitellogenin production. Increased liver weight was associated with high maturation response. Mean LW of sacrificed control eels did not differ between the 3 yr. However, great individual differences were observed in the LW of maturing eels. Individuals that showed an increase in LW at the end of their trial also exhibited a high maturation response. The liver evolved differently in eels throughout sexual maturation. As it is a target organ for many pollutants, ecotoxicological studies should aim at investigating whether these differences in the trends in LW may have been partly related to differences in individual contamination levels.

\section{Influence of body length and age}

The age and size at which eels undergo silvering are extremely variable, and the reason for this is unknown. One of the objectives of this study was to investigate whether this variability in length and age has an effect on the eel's maturation capacity, defined here by the weight of ovaries and vitellogenin level. Effect of body size on gonad development was investigated through 
the relationship between body length and raw gonad weight. The trade-off between immediate reproductive success and gain by postponed reproduction has been discussed. As with most species, female eels would tend to maximise their size at migration for increased fecundity (Wenner \& Musick 1974, Vøllestad \& Jonsson 1986, Helfman et al. 1987). However, this strategy would be modulated by the environment (Vøllestad 1992), and size at migration would be smaller in a slow growth environment (Oliveira 1999, Jellyman 2001, Jessop et al. 2004). According to Svedäng et al. (1996) eels would leave at the earliest possible opportunity and this would be determined by energy reserves (Larsson et al. 1990). In France, the smallest silvering females measure around $450 \mathrm{~mm}$ in body length (Durif et al. 2005). Here, we showed that for this size class (up to $500 \mathrm{~mm}$ ), increase in gonad weight was negligible even after 17 wk of gonadotropic treatment. In their natural environment, silver eels of this size class would apparently not become effective spawners. Therefore, why would eels 'decide' to migrate at such a small size? Silvering seems to be triggered by a period of high growth in spring (Fontaine 1994, Durif et al. 2005). It is possible that this process is initiated in all eels once they have reached a minimal size $(450 \mathrm{~mm})$. However, only part of these individuals would actually complete their journey to the Sargasso Sea; others may halt further downstream, in coastal or estuarine areas, revert to a yellow phase (Durif et al. 2005, this study), and start feeding again when temperatures increase at the end of winter. Another possibility is that, although their reproductive output will be limited, small silver-phase eels would minimise their size at migration in a highly contaminated environment. This is supported by the present study, as the smallest and youngest eels came from the location (Sainte-Eulalie) which displayed the lowest water quality (in terms of organic matter and mineral pollution) and highest Anguillicola crassus prevalence (93\%).

For upper size classes (starting at $600 \mathrm{~mm}$ ) gonad weight increased exponentially with increasing body length; as a consequence, large silver eels developed proportionally more gonads than small silver eels. The best gonad weight:body length ratio was found for eels in the $700 \mathrm{~mm}$ size class. This would be the optimal length for eels to reproduce.

There is wide variability in the age distribution of silver eels (Rossi \& Colombo 1976, Vøllestad \& Jonsson 1986, Poole \& Reynolds 1996, Svedäng et al. 1996). In the present study, age ranged from 5 to $24 \mathrm{yr}$. Age was positively correlated with liver weight and condition factor; therefore the oldest eels (regardless of their body length) had the best condition in terms of energy stores. Thus, it appears that eels benefit from delaying their reproduction. This is supported by the recent findings of Palstra et al. (in press), who showed that the amount of fat in the gonads of ripe females was positively related to the age of the eel. Interestingly, age was also correlated with vitellogenin. This may imply that the advantage for eels of having a greater age at reproduction may not only result from higher energy stores, but from a more efficient vitellogenesis.

Acknowledgements. Funding was provided by the European Union (Eelrep: Project Q5RS-2001-01836). The holding tanks were funded by the Regional Council of Aquitaine. We thank T. Rouault (Cemagref) for the use of the facility, M. Pelard (Cemagref) and D. Mercier (Cemagref) for their extremely valuable assistance in the setup and throughout the experiments. We are very grateful to Dr M. Sbaihi (Eelrep, MNHN) and D. Rooke (European Program Leonardo da Vinci, MNHN) for their participation in organ sampling and VTG measurement, to A. Guibert, C. Sechet, and I. Ortusi for the weekly surveys and injections. Sampling of eels from the Rhine was made possible by Prof. F. Meunier.

\section{LITERATURE CITED}

Burzawa-Gerard E, Dumas-Vidal A (1991) Effects of 17-estradiol and carp gonadotropin on vitellogenesis in normal and hypophysectomised European silver female eel (Anguilla anguilla L.) employing a homologous radioimmunoassay for vitellogenin. Gen Comp Endocrinol 84:264-276

Burzawa-Gérard E, Baloche S, Leloup-Hatey J, Le Menn F, Messaouri H, Nunez-Rodriguez J, Peyon P, Roger C (1994) Ovogenèse chez l'anguille (Anguilla anguilla L.): ultrastructure de l'ovaire à différents stades de développement et implication des lipoprotéines au cours de la vitellogenèse. Bull Fr Pêche Piscic 335:213-233

Castonguay M, Hodson PV, Moriarty C, Drinkwater KF, Jessop BM (1994) Is there a role of ocean environment in American and European eel decline. Fish Oceanogr 3: 197-203

Claytor RR, MacCrimmon HR (1987) Partitioning size from morphometric data: a comparison of five statistical procedures used in fisheries stock identification research. Can Tech Rep Fish Aquat Sci 1531:1-23

Dekker W (2003) Status of the European eel stock and fisheries. In: Aida K, Tsukamoto K, Yamauchi K (eds) Eel biology. Springer-Verlag, Tokyo, p 237-254

Desaunay Y, Guerault D (1997) Seasonal and long-term changes in biometrics of eel larvae: a possible relationship between recruitment variation and North Atlantic ecosystem productivity. J Fish Biol 51:317-339

Dufour S, Lopez E, Le Belle N, Baloche S, Fontaine YA (1988) Stimulation of gonadotropin release and of ovarian development by the administration of a gonadoliberin agonist and pretreated with estradiol. Gen Comp Endocrinol 70: $20-30$

Dufour S, Montero M, Le Belle N, Bassompierre M, King JA, Millar RP, Peter RE, Fontaine YA (1993) Differential distribution and response to experimental sexual maturation of two forms of brain gonadotropin-releasing hormone (GnRH) in the European eel, Anguilla anguilla. Fish Physiol Biochem 11:99-106

Dufour S, Burzawa-Gérard E, Le Belle N, Sbaihi M, Vidal B (2003) Reproductive endocrinology of the European eel, Anguilla anguilla. In: Aida K, Tsukamoto K, Yamauchi K (eds) Eel biology. Springer-Verlag, Tokyo, p 373-383 
Durif C, Elie P (in press) Morphological discrimination of the silvering stages of the European eel. In: Casselman JM, Cairns DK (eds) Eels at the edge: science, status, and conservation concerns. Proc 2003 Int Eel Symp. Am Fish Soc Symp, Bethesda, MD

Durif C, Gosset C, Rives J, Travade F, Elie P (2003) Behavioral study of downstream migrating eels by radio-telemetry at a small hydroelectric power plant. In: Dixon DA (ed) Biology, management, and protection of catadromous eels. Am Fish Soc Symp 33, Bethesda, MD, p 343-356

Durif C, Dufour S, Elie P (2005) The silvering process of Anguilla anguilla: a new classification from the yellow resident to the silver migrating stage. J Fish Biol 66: $1025-1043$

Feunteun E (2002) Management and restoration of European eel population (Anguilla anguilla): an impossible bargain. Ecol Eng 18:575-591

Fontaine M, Bertrand E, Lopez E, Callamand O (1964) Sur la maturation des organes génitaux de l'anguille femelle (Anguilla anguilla L.) et l'émission spontanée des œufs en aquarium. C R Hebd Séances Acad Sci 259:2907-2910

Fontaine YA (1994) L'argenture de l'anguille: métamorphose, anticipation, adaptation. Bull Fr Pêche Piscic 335: 171-186

Helfman GS, Facey DE, Hales LS (1987) Reproductive ecology of the American eel. In: Dadswell MJ, Klauda RJ, Moffit CM, Saunders RL, Rulifson RA, Cooper JE (eds) Common strategies of anadromous and catadromous fishes, Vol 1. Am Fish Soc Symp 1, Bethesda, MD, p 42-56

ICES (1999) Report of the ICES Advisory Committee on Fisheries Management, 1998. Part 2. Int Counc Explor Sea Coop Res Rep 229:1-446

ICES (2002) Report of the ICES/EIFAC Working group on eels. Int Counc Explor Sea Comm Meet ACFM:03:1-55

Jellyman DJ (2001) The influence of growth rate on the size of migrating female eels in Lake Ellesmere, New Zealand. J Fish Biol 58:725-736

Jessop BM, Shiao JC, Iizuka Y, Tzeng WN (2004) Variation in the annual growth, by sex and migration history, of silver American eels Anguilla rostrata. Mar Ecol Prog Ser 272: 231-244

Kagawa H (2003) Artificial induction of oocyte maturation and ovulation. In: Aida K, Tsukamoto K, Yamauchi K (eds) Eel biology. Springer-Verlag, Tokyo, p 401-414

Kagawa H, Iinuma N, Tanaka H, Ohta H Okuzawa K (1998) Effect of rearing period in seawater on induced maturation in female Japanese eel Anguilla japonica. Fish Sci 64: 77-82

Kleckner RC, McCleave JD (1988) The northern limit of spawning by Atlantic eels (Anguilla spp.) in the Sargasso Sea in relation to thermal fronts and surface water masses. J Mar Res 46:647-667

Knights B (2003) A review of the possible impacts of longterm oceanic and climate changes and fishing mortality on recruitment of anguillid eels of the Northern Hemisphere. Sci Total Environ 310:237-244

Larsson P, Hamrin S, Okla A (1990) Fat content as a factor inducing migratory behaviour in the eel (Anguilla anguilla L.) to the Sargasso Sea. Naturwissenschaften 77: $488-490$

LeCren ED (1951) The length-weight relationship and seasonal cycle in gonad weight and condition in perch Perca fluviatilis. J Anim Ecol 20:201-219

Lokman M, Young G (2000) Induced spawning and early on- togeny of New Zealand freshwater eels (Anguilla dieffenbachii and A. australis). NZ J Mar Freshw Res 34:135-145

McCleave JD, Brickley PJ, O'Brien KM, Kistner DA, Wong MW, Gallagher M, Watson M (1998) Do leptocephali of the European eel swim to reach continental waters? Status of the question. J Mar Biol Assoc UK 78:285-306

Moriarty C (1986) Variations in elver abundance at European catching stations from 1958 to 1985. Vie Milieu 36: 233-235

Ohta H, Kagawa H, Tanaka H, Okuzawa K, Iinuma N, Hirose K (1997) Artificial induction of maturation and fertilization in the Japanese eel, Anguilla japonica. Fish Physiol Biochem 17:163-169

Oliveira K (1999) Life history characteristics and strategies of the American eel, Anguilla rostrata. Can J Fish Aquat Sci 56:795-802

Palstra AP, Cohen EGH, Niemantsverdriet PRW, van Ginneken V, van den Thillart G (2005) Artificial maturation and reproduction of European silver eel: development of oocytes during final maturation. Aquaculture 249:533-547

Palstra AP, van Ginneken VJT, Murk AJ, van den Thillart GEEJM (in press) Are dioxin-like contaminants responsible for the eel (Anguilla anguilla) drama? Naturwissenschaften

Pedersen BH (2004) Fertilisation of eggs, rate of embryonic development and hatching following induced maturation of the European eel Anguilla anguilla. Aquaculture 224: 323-338

Poole W, Reynolds JD (1996) Growth rate and age at migration of Anguilla anguilla. J Fish Biol 48:633-642

Prokhorchik GA (1986) Postembryonic development of European eel, Anguilla anguilla, under experimental conditions. J Ichthyol 26:121-127

Rossi R, Colombo G (1976) Some investigations on growth of silver eels of North Adriatic lagoons. Boll Pesca Piscic Idrobiol 31:283-289

Schmidt J (1922) The breeding places of the eel. Philos Trans R Soc Lond B 211:179-208

Sorensen PW, Winn HE (1984) The induction of maturation and ovulation in American eels, Anguilla rostrata (LeSueur) and the relevance of chemical and visual cues to male spawning behaviour. J Fish Biol 25:261-268

Svedäng H, Neuman E, Wickström H (1996) Maturation patterns in female European eel: age and size at the silver eel stage. J Fish Biol 48:342-351

Tesch FW (1982) The Sargasso Sea eel expedition 1979. Helgol Meeresunters 35:263-277

Tesch FW, Wegner G (1990) The distribution of small larvae of Anguilla sp. related to hydrographic conditions in 1981 between Bermuda and Puerto Rico. Int Rev Gesamten Hydrobiol 75:845-858

Van den Thillart G, van Ginneken V, Korner F, Heijmans R, van der Linden R, Gluvers A (2004) Endurance swimming of the European eel. J Fish Biol 65:312-318

Vøllestad LA (1992) Geographic variation in age and length at metamorphosis of maturing European eel: environmental effects and phenotypic plasticity. J Anim Ecol 61:41-48

Vøllestad LA, Jonsson B (1986) Life-history characteristics of the European eel Anguilla anguilla in the Imsa River, Norway. Trans Am Fish Soc 115:864-871

Wenner CA, Musick JA (1974) Fecundity and gonadal observations of the American eel, Anguilla rostrata, migrating from Chesapeake Bay, Virginia. J Fish Res Board Can 31: $1387-1391$

Submitted: July 19, 2005; Accepted: February 16, 2006

Proofs received from author(s): September 28, 2006 